\title{
Diurnal variations of trace metals and heterotrophic bacterioplankton concentration in a small boreal lake of the White Sea basin
}

\author{
Liudmila S. Shirokova $^{1}$, Oleg S. Pokrovsky ${ }^{2 *}$, Jérôme Viers ${ }^{2}$, Sergey I. Klimov ${ }^{1}$, \\ Olga Yu. Moreva ${ }^{1}$, Svetlana A. Zabelina ${ }^{1}$, Taissia Ya. Vorobieva ${ }^{1}$ and Bernard Dupré ${ }^{2}$ \\ ${ }^{1}$ Laboratory of Freshwater and Marine Ecosystems (LFME), Institute of Ecological Problems of the North, 163061, \\ Nab. Severnoi Dviny, 23, 163000 Arkhangelsk, Russia \\ 2 LMTG CNRS, Université Paul Sabatier, Observatoire Midi-Pyrénées, 14 avenue Édouard Belin, 31400 Toulouse, France
}

Received 2 August 2009; Accepted 3 March 2010

\begin{abstract}
This work represents a concerted effort aimed at understanding the microbiological and chemical evolution of a small boreal lake during the diurnal cycle of photosynthesis. We studied diurnal variation of $\sim 40$ dissolved macro- and trace elements, organic carbon and bacterial population dynamics in the surface and bottom water layer of the shallow Vilno Lake in the White Sea basin. Four-days continuous measurements with $6 \mathrm{~h}$ sampling steps both at the surface $(0.5 \mathrm{~m})$ and on the bottom $(4.0 \mathrm{~m}$ depth) during no-bloom periods revealed constant concentrations (within $\pm 20-30 \%$ ) of all major elements ( $\mathrm{Na}, \mathrm{Mg}, \mathrm{Si}, \mathrm{K}, \mathrm{Ca}$ ), organic and inorganic carbon and most trace elements (B, V, Cr, Fe, Cu, Ga, As, Rb, Sr, Y, Zr, Sb, Cs, Ba, all REEs, $\mathrm{Hf}, \mathrm{Pb}, \mathrm{Th}, \mathrm{U})$. At the same time, the concentration of some biologically important trace metals (Mo, Mn, Co, Cd) was subjected to variations partially reflecting the change of bacterioplankton concentration. This work enables two types of element behavior to be distinguished during photosynthesis in the water column - constant concentration and sinusoidal variations - depending on their speciation in solution and their affinity to aquatic microorganisms.
\end{abstract}

Key words: Boreal lake / trace metals / speciation / heterotrophic bacteria / diurnal cycle

\section{Introduction}

Establishing functional relationships between the biological activity of microorganisms and fluxes and speciation of trace metals is among the major objectives of the environmental geochemistry. Quantitative characterization of these relationships in water systems requires detailed analysis of microbial population, phytoplankton, dissolved organic carbon and major and trace elements. Boreal lakes represent an important and highly attractive subject of research in view of various environmental issues raised in the subarctic region, including, for example, pristine concentrations of metals and trace elements that are most likely to be affected by the human impact (Roederer, 1991; de Caritat et al., 1996). Another important environmental issue is the fate of organic carbon in lakes that is likely to significantly control the $\mathrm{CO}_{2}$ balance in high latitudes (Smith et al., 2004; Shirokova et al., 2009). High concentrations of dissolved

\footnotetext{
*Corresponding author: oleg@lmtg.obs-mip.fr
}

organic matter (DOM) and thus, the colloidal status of most trace elements (TE) is the most important characteristic feature of TE geochemistry in European Russian Arctic zone (Pokrovsky and Schott, 2002; Pokrovsky et al., 2005). This change in metal speciation (i.e., the proportion of organo-mineral colloids and humic/fulvic complexes of trace metals, size distribution in colloidal fraction) between different water reservoirs or in the water column is expected to be controlled by: (1) biological processes of primary production/mineralisation and the release of organic exudates, both on diurnal (photosynthesis) and monthly (summer bloom, spring and autumn overturn) scales occurring in the water column; and (2) hydrological conditions of the watershed that controls the delivery of allochtonous organic matter from the soil reservoirs via riverine inflow, which in turn, depends on intra-soil processes, watershed lithology, and, if present, anthropogenic and atmospheric input.

Diurnal variation of major hydrochemical and biological parameters in the lake waters have been studied since the beginning of the last century (i.e., Rose et al., 1925; 
Hutchinson, 1957; Eiler et al., 2006). Less in known about the fate of trace metals, except those involved in redox cycles linked to photoreduction that has been extensively investigated (McMahon, 1969; Emmenegger et al., 2001). There is a large body of literature on trace element geochemistry in temperate lakes (e.g., Hamilton-Taylor and Willis, 1990; Noel et al., 1990; Balistrieri, 1992; Viollier et al., 1995, 1997; Hamilton-Taylor et al., 1996, 2005; Nriagu et al., 1996; Falkner et al., 1997; Albéric et al., 2000), including detailed seasonal observations. However the diurnal patterns of trace metal concentration remain poorly investigated. In contrast, diurnal variations of trace elements were extensively studied on marine and coastal systems (Luengen et al., 2007) and in rivers (Brick and Moore, 1996; Jones et al., 2004; Gammons et al., $2005 \mathrm{a}, 2005 \mathrm{~b})$. In the latter, these variations are known to be induced by change in environmental conditions such as temperature and biological activity and are strongly controlled by adsorption processes (e.g., Nimick et al., 2005; Parker et al., 2007). However, relationships of chemical and biological parameters kinetics with temperature and photochemical regime of redox sensitive elements are virtually unknown for the lakes of high latitudes especially those that do not bear any anthropogenic pressure. At the same time, compared to rivers, small lakes represent a far better object for testing the diurnal variations of chemical and biological parameters due to the stable functional processes of primary production bacterial mineralization. In lakes, such links are minimally influenced by short-term variations of external factors such as hydrology, human activity, allochtonous soil and groundwater inputs. In boreal waters, most trace elements and oligo-metals are associated with organo-mineral colloids of allochtonous origin such as soil humic and fulvic acids. The bioavailability of these colloids for autotrophic phytoplankton is rather low (Xue and Sigg, 1993). In contrast, heterotrophic bacterioplankton is known to mineralize dissolved organic matter of both allochtonous and autochthonous origin (Tranvik, 1988, 1989, 1994; Kritzberg et al., 2004) and thus can potentially liberate or consume associated trace metals.

In the present work, we monitored the trace element and bacterioplankton concentration in the water column of a small lake Vilno of the White Sea basin. We characterized colloidal speciation and analyzed concentrations of $\sim 40$ major and trace elements and two groups of heterotrophic bacteria in the surface and bottom layers over four days of continuous observation in order to address two following question: (1) Are there diurnal variations of trace element concentration at different depths, and (2) Is there a link of these variations with major hydrochemical parameters and the heterotrophic bacterio-plankton concentration in the water column? An additional motivation for this work was to test whether a single sampling of the small lake surface may serve as representative of trace elements concentration for a longer period of observation. It is anticipated that addressing these objectives will improve our knowledge of factors controlling the biogeochemical cycles of trace elements



Fig. 1. Schematic map of the region and Lake Vilno. Asterisk represents the monitoring station.

and biologically important heavy metals migration in lake systems of high latitudes.

\section{Materials and methods}

We studied a small non-stratified Lake Vilno located in the Arkhangelsk region (Russia) within the state protected territory of Kenozersky National Park $\left(61^{\circ} 81^{\prime} \mathrm{N} ; 38^{\circ} 07^{\prime} \mathrm{E}\right.$, Fig. 1). The studied area can be considered as pristine environment with natural concentrations of elements because of the absence of any industrial or agricultural activity and the limited accessibility. The watershed lithology is represented by glacial moraine (products of granite-gneisses erosion) and carbonate rocks. The lake has overall surface area of $2.57 \mathrm{~km}^{2}$ and an average depth of $3 \mathrm{~m}$. There is no inlet in this lake and only one small outlet. Sampling was performed on 17-22 July 2007 at essentially anticyclone conditions with in-situ measurements of $\mathrm{pH}$, temperature, redox potential and dissolved oxygen. Water samples were collected from the surface $(0.5 \mathrm{~m} \mathrm{depth})$ and from the bottom ( $4.0 \mathrm{~m}$ depth) each $6 \mathrm{~h}$ and immediately filtered through acetate cellulose membrane $(0.22 \mu \mathrm{m})$ filters.

The $\mathrm{pH}$ was measured using a combined Schott-Geräte electrode calibrated against NIST buffer solutions ( $\mathrm{pH}=4.00$ and 6.86 at $25^{\circ} \mathrm{C}$ ), with an accuracy of \pm 0.02 $\mathrm{pH}$ units. Clean trace-metal technique was employed throughout samples and collecting, filtration and analysis. Samples were collected on the monitoring station from a PVC boat having no metal parts submerged in the water using a polycarbonate water sampler for ultraclean water collection (Aquatic Research ${ }^{\circledR}$ ). Plastic gloves were always used during handling of the samples. The water samples were immediately filtered through sterile, Minisart ${ }^{\circledR}$ filter units (Sartorius, acetate cellulose filter) with pore sizes of $0.22 \mu \mathrm{m}$. The first $20 \mathrm{~mL}$ of the filtrate was systematically 
discarded. The biological availability of trace metal is known to be fully controlled by their speciation in aqueous solution. For example, permeation of free ions through the biological membrane is determined by ion transport channels having approx. 600 Da molecular size. Conventional filtration through a $0.22 \mu \mathrm{m}$ membrane cannot, therefore, account for the bioavailability of metals, and thus fine size separation procedure via ultrafiltration/ dialysis is necessary. In order to better characterize trace element speciation in studied lake, we performed in-situ dialysis at the surface $(0.5 \mathrm{~m}$ depth). Dialysis experiments were performed using $20-50 \mathrm{~mL}$ precleaned dialysis bags placed directly in the lake water. Similar technique has been used to account for metal speciation both in the water column and in the pore waters (Carignan et al., 1985; Alfaro-De la Torre et al., 2000; Gimpel et al., 2003). The duration of this dialysis procedure was between 24 and 48 h. Pokrovsky et al. (2005) showed in laboratory experiments that, for both 1 and 6-8 $\mathrm{kDa}$ membranes, an equilibrium distribution is attained within 6-12 h, in agreement with the manufacturer's specifications. At the same time, Carignan et al. (1985) argued that much longer equilibration time is necessary to achieve equilibrium dialysis distribution in porewaters. However, we would like to stress that diffusion control on intra-membrane transport in extremely stagnant pore waters is much slower than that in well-agitated, shallow water column of the lake. For dialysis experiments, EDTA-cleaned trace-metal pure SpectraPor $7^{\circledR}$ dialysis membranes made of regenerated cellulose and having pore sizes of $1 \mathrm{kDa}$ (approximately $1 \mathrm{~nm}$ ) were thoroughly washed in $0.1 \mathrm{M}$ double-distilled $\mathrm{HNO}_{3}$, ultrapure water, filled with ultrapure MQ deionized water and then placed into natural water. The efficiency of the dialysis procedure was evaluated by comparing major anion concentrations (e.g., $\mathrm{Cl}^{-}$and $\mathrm{SO}_{4}{ }^{2-}$ ) or neutral species $\left(\mathrm{H}_{4} \mathrm{SiO}_{4}{ }^{\circ}\right)$ not associated with colloids between the dialysis bag and the external solution. These concentrations were always identical to within $\pm 10 \%$, suggesting an equilibrium distribution of dissolved components.

Filtered or dialysed solutions for cations and trace element analyses were acidified $(\mathrm{pH}=2)$ with ultrapure double-distilled $\mathrm{HNO}_{3}$ and stored in HDPE bottles previously washed with ultrapure $0.1 \mathrm{M} \mathrm{HCl}$ and rinsed with MilliQ deionized water. The preparation of sampling bottles was performed in a clean bench room class A 10000 . Filtered samples for DOC analyses were collected in a pyrolysed sterile Pyrex glass tube. For all major and most trace elements except $\mathrm{Zn}$, concentrations in blanks were below detection limits. Zn concentration in blanks was sometimes 2-3 times higher than the detection limits; however, it was still a factor of 5 to 10 lower than the sample concentration. Aqueous silica concentrations were determined colorimetrically (molybdate blue method) using a Technicon autoanalyzer II, with an uncertainty of $2 \%$. Alkalinity was measured by potentiometric titration with $\mathrm{HCl}$ by automated titrator (Metrohm 716 DMS Titrino) using a Gran method with a detection limit of $10^{-5} \mathrm{M}$ and an uncertainty of $2 \%$. DOC was analysed using a Carbon Total Analyzer (Shimadzu TOC 6000) with an uncertainty better than $3 \%$. Major and trace anion concentrations $\left(\mathrm{Cl}^{-}, \mathrm{SO}_{4}{ }^{2-}, \mathrm{F}^{-}, \mathrm{NO}_{3}{ }^{-}\right.$and $\left.\Sigma \mathrm{PO}_{4}\right)$ were measured by ion chromatography (HPLC, Dionex ICS 2000) with an uncertainty of $2 \%$. Calcium, magnesium, sodium, and potassium concentrations were determined with an uncertainty of $1-2 \%$ using a Perkin-Elmer 5100PC atomic absorption spectrometer. Trace elements (TE) were determined without preconcentration by ICP-MS Agilent 8000. Indium and rhenium were used as external standards. The international geostandard SLRS-4 (Riverine Water Reference Material for Trace Metals certified by the National Research Council of Canada) was used to check the accuracy and reproducibility of each analysis (Yeghicheyan et al., 2001). We obtained a good agreement between replicated measurements of SLRS-4 and the certified values (relative difference $<10 \%$ SD on repeated measurements), except for B and P (30\%).

Chlorophyl a was measured by spectrophotometry at six different wavelengths after extraction from $0.45 \mu \mathrm{m}$ filter using $90 \%$ acetone. For this, from 1 to $1.5 \mathrm{~L}$ of the lake water was processed. Typical analytical uncertainty of Chl a determination is $\pm 10 \%$ in the concentration range 0.1 to $10 \mu \mathrm{g} . \mathrm{L}^{-1}$. Samples for microbiological analyses were collected in sterile $250-\mathrm{mL}$ flacons and stored less than $2 \mathrm{~h}$ in a portable cooler at $5{ }^{\circ} \mathrm{C}$. Active bacteria number count (colony forming units, CFU.mL ${ }^{-1}$ ) was performed using Petri dishes inoculation $(0.1$ to $1.0 \mathrm{~mL}$ of lake water in three replicates) performed in specially organized microbiological field laboratory. For this, internal space of metal-free camping tent was maximally cleaned and sterilized by UV irradiation. All manipulations were performed in the vicinity of open flame on thoroughly alcohol- and detergent-treated microbiological table. Samples were inoculated on Nutrient Agar (5 g. $\mathrm{L}^{-1}$ beef extract, 5 g. $\mathrm{L}^{-1}$ gelatine peptone, 15 g. $\mathrm{L}^{-1}$ bacteriological agar, $\mathrm{pH}=6.8 \pm 0.2$ at $25^{\circ} \mathrm{C}$ ) to determine the total number of heterotrophic bacteria. Difco ${ }^{(i x}$ agar (granulated powder, Lot No 6290083) inoculation was used to assess the number of oligotrophic bacteria. Inoculation of blanks was routinely performed to assure the absence of contamination from external environments.

\section{Results and discussion}

\section{Element speciation in colloids}

In-situ dialysis procedure revealed that $>50 \%$ of trivalent and tetravalent elements are in colloidal form ( $1 \mathrm{kDa}-0.22 \mu \mathrm{m}$ fraction), whereas alkaline and alkalineearth metals, neutral species ( $\mathrm{Si}, \mathrm{Sb}, \mathrm{As})$ and anions (Mo, $\mathrm{V})$ are essentially present in their inorganic (ionic) forms. Specifically, according to their association with these colloids, two groups of elements can be distinguished: (i) species that are weakly affected by size separation procedure and present in the form of true dissolved inorganic species ( $\max 20-30 \%$ of colloidal fraction) such as $\mathrm{Ca}, \mathrm{Mg}, \mathrm{Li}, \mathrm{Na}, \mathrm{K}, \mathrm{Cs}, \mathrm{Si}, \mathrm{Ba}, \mathrm{Sr}, \mathrm{Rb}, \mathrm{As}, \mathrm{Sb}$, 

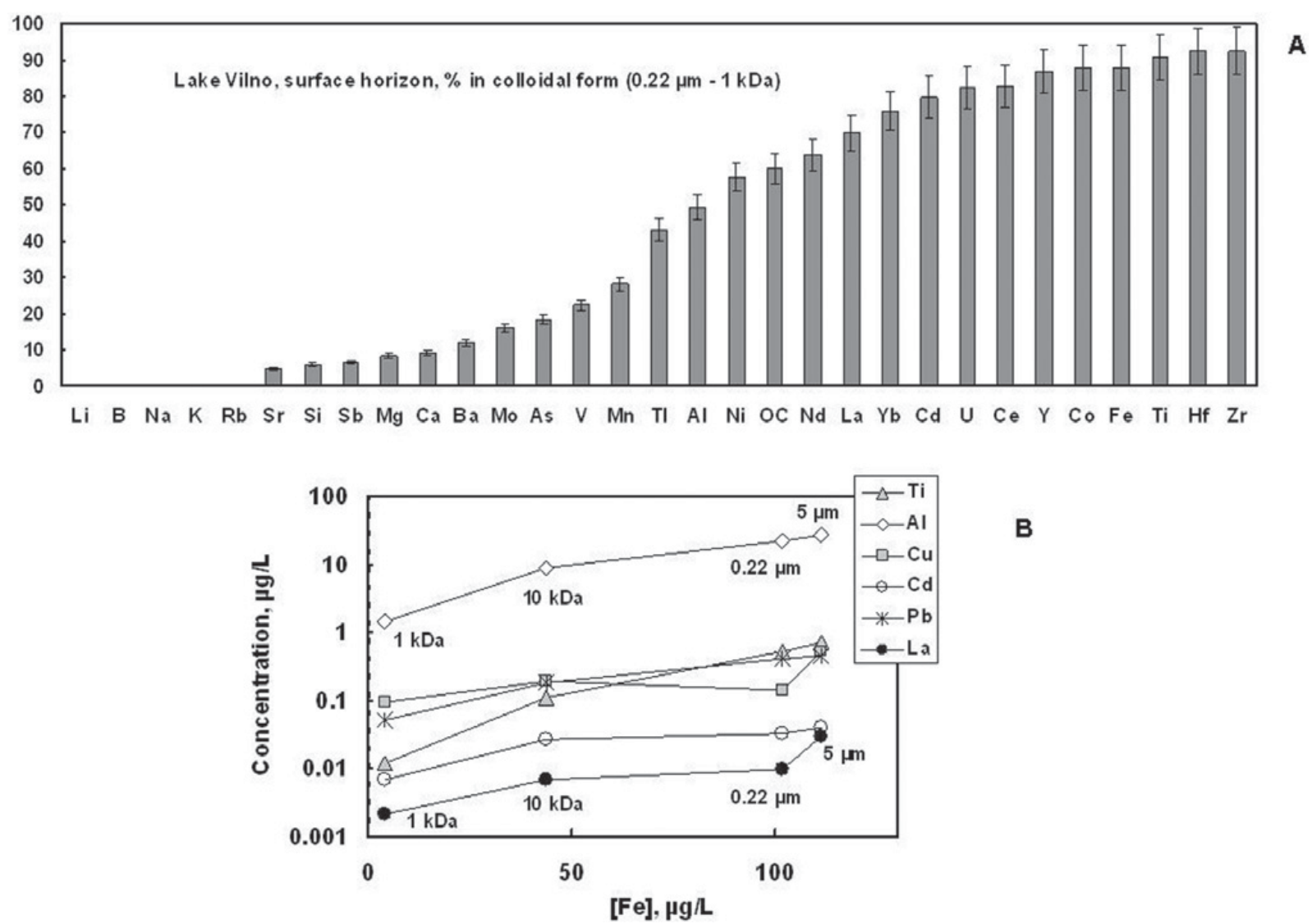

B

Fig. 2. Speciation of major and trace elements in surface water of Lake Vilno, Kenozersky national park. A: Percentage of colloidal fraction for different major and trace elements in surface waters. B: Concentrations of trace elements in cascade filtration and ultrafiltration experiments as a function of Fe concentration in the swamp waters adjacent to Lake Vilno.

Mo and Mn; and (ii) elements significantly affected by dialysis procedure with $>40-50 \%$ being concentrated in colloids (1 kDa - $0.22 \mu \mathrm{m})$ : Al, Ti, Ni, Co, Y, REE, Pb, Zr, $\mathrm{Hf}, \mathrm{Th}, \mathrm{U})$. A stack diagram of element proportion in colloidal form is illustrated in Figure 2A. The affinity of chemical elements towards colloidal fraction is fairly well documented in many boreal rivers and streams (e.g., Ingri et al., 2000; Pokrovsky and Schott, 2002; Pokrovsky et al., 2006; Dahlqvist et al., 2007; Vasyukova et al., 2010), and is most likely linked to their presence in the form of Fe-rich, organic-matter stabilized aggregates of large $(10 \mathrm{kDa}-0.22 \mu \mathrm{m})$ molecular weight. This is further illustrated by ultrafiltration pattern of TE partitioning in colloids assessed from the experiments performed at the wetland surface water adjacent to the lake Vilno (Fig. 2B). There is a strong decrease of insoluble trace element concentration with decrease of Fe concentration in colloids that occurs between $10 \mathrm{kDa}$ and $0.22 \mu \mathrm{m}$. Further decrease also occurs upon filtration through $1 \mathrm{kDa}$ membrane.

\section{Element concentration variation during the diurnal photosynthesis cycle}

Water temperature variations both at 0.5 and $4 \mathrm{~m}$ depth were rather minor $\left( \pm 1-1.5^{\circ}\right)$ although followed some diurnal cycle (Fig. 3A). It is well known that $\mathrm{pH}$ is the most sensitive parameter of the primary production mineralization processes. Indeed, this parameter demonstrates clear diurnal periodicity, both at the bottom and on the surface where it changes from 6.7 to 7.2 (Fig. 3B). Note that the phytoplankton bloom in lakes of studied region usually occurs in August and thus the present study conducted in July is not addressing the biogeochemistry of the lake water column during the bloom period. Dissolved oxygen concentration demonstrated non-systematic variations in the course of observation and no clear maximum or minimum was detected neither during the afternoon period or night measurements except a global minimum at the beginning of third day of observation (Fig. 3C). The DOC remained constant with non-systematic $( \pm 30 \%)$ fluctuation from the average value of $8.9 \pm 0.3 \mathrm{mg} . \mathrm{L}^{-1}$ (Fig. 3D). Carbonate alkalinity was subjected to minimal variations remaining constant within $435 \pm 5 \mu \mathrm{mol}$ C.L ${ }^{-1}$ (30 measurements at 0.5 and $4.0 \mathrm{~m}$ depth, not shown). Chlorophyll a (5 measurements at $0.5 \mathrm{~m}$ depth) varied from 3.0 to $4.1 \mu \mathrm{g} . \mathrm{L}^{-1}$ with a minimum value observed in the morning of the third day of observation. These measurements are compatible with the absence of bloom and relatively weak primary production during the observation period. Apparently, the pool of allochtonous dissolved organic carbon was very weakly affected 
A



C

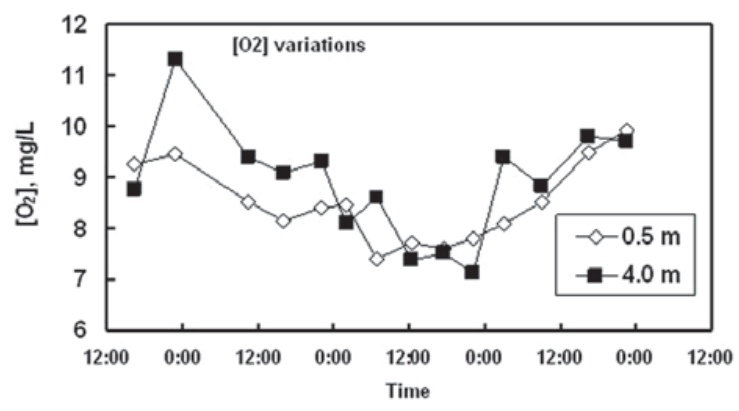

B
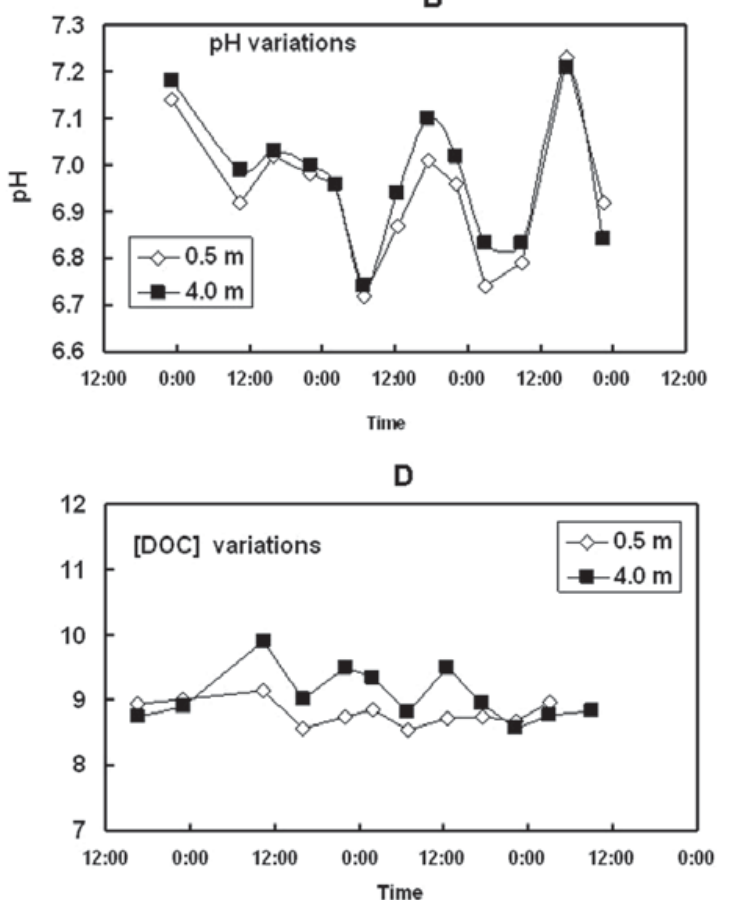

Fig. 3. Diurnal temperature (A), $\mathrm{pH}(\mathrm{B}), \mathrm{O}_{2}(\mathrm{C})$ and dissolved organic carbon (D) concentration variations in surface and bottom waters of Lake Vilno at the monitoring station.

by autochtonous production of phytoplankton exometabolites which could feed the microbial loop of the system.

During four days of continuous observations on both depths, we have not detected significant variation (i.e., $\geq 30 \%$ ) of most major and trace elements (B, Na, Mg, Si, $\mathrm{K}, \mathrm{Ca}, \mathrm{V}, \mathrm{Cr}, \mathrm{Co}, \mathrm{Fe}, \mathrm{Cu}, \mathrm{Ga}, \mathrm{As}, \mathrm{Rb}, \mathrm{Sr}, \mathrm{Y}, \mathrm{Zr}, \mathrm{Sb}, \mathrm{Cs}$, $\mathrm{Ba}$, all REEs, $\mathrm{Hf}, \mathrm{Pb}, \mathrm{Th}, \mathrm{U})$ concentrations as illustrated for some of them in Figure 4. At the depth of $4 \mathrm{~m}$, we observed some non-systematic variations of $\mathrm{Al}, \mathrm{Ti}, \mathrm{Mo}$ and $\mathrm{Pb}$ concentrations that never exceeded $30-50 \%$ deviation from the average value. Overall, we observed a quite high stability of chemical composition of the lake water, which signifies that the role of external fluctuations, internal lake processes, anthropogenic or atmospheric contaminations were negligible during full period of observation. This result is important from methodological point of view as it suggests that for most major and trace elements dissolved in the water column, a single one-time sampling from the surface at any period of the day is sufficiently representative for a larger temporal and spatial range of observation.

Three typical oligoelements-heavy metals (Fe, $\mathrm{Zn}, \mathrm{Cu}$ ) demonstrate highly contrasting behavior in the course of observation. While $\mathrm{Cu}$ and $\mathrm{Fe}$ concentrations remain rather stable $( \pm 20-30 \%$ deviation from average) over a full period of sampling, $\mathrm{Zn}$ concentration is subjected to significant variations achieving one order of magnitude (Fig. 5). These variations are not compatible with those of $\mathrm{pH}$ as it can be seen from the comparison of diurnal $\mathrm{pH}$ variations demonstrating at least three day-time maximums over the 4-days observation period (Fig. 3B) and variations of $\mathrm{Zn}$ concentration demonstrating only one day-time maximum. The variation of $\mathrm{Zn}$ concentration in the surface water of lake Vilno is almost an order of magnitude higher than that of the $\mathrm{Chl}$ a. The independence of $\mathrm{Zn}$ on $\mathrm{pH}$ and other macroscopic parameters of solution variations is at first glance surprising because $\mathrm{Zn}$ uptake by phytoplankton is strongly $\mathrm{pH}$-dependent (Gélabert et al., 2006; Tripathi et al., 2009) and $\mathrm{Zn}$ concentration during the bloom often follows that of the Chl a (Luengen et al., 2007). Moreover, the pH is known to be the governing factor of metal adsorption on the surface of photosynthetic microorganisms such as diatoms or cyanobacteria (Gélabert et al., 2007; Pokrovsky et al., 2008a, 2008b). However, we would like to underline that relatively small $\mathrm{pH}$ variations (from 6.7 to 7.2 ) may not be sufficient to control the adsorption and uptake process from the bulk of lake water; rather, these processes are dominated by local $\mathrm{pH}$ gradients in the pristine layer around the photosynthesizing cells.

It is possible that the absence of bloom during studied period does not allow testing these dependences for selected boreal lake. For copper, even during the bloom, this element behaves independently on biological and hydrochemical parameters (Luengen et al., 2007). Independence of $\mathrm{Cu}$ concentration (unlike $\mathrm{Zn}$ ) from that of chlorophyll and biogenic components has been also reported for England lakes during the diatom bloom period (Reynolds and Hamilton-Taylor, 1992). To our knowledge, such information on boreal lakes rich on dissolved organic matter is lacking. Our dialysis results demonstrate that almost $90 \%$ of $\mathrm{Fe}$ is in colloidal form. One can suggest that the strong complexation of $\mathrm{Fe}$ and $\mathrm{Cu}$ with colloidal organic matter of essentially allochtonous origin 



Fig. 4. Diurnal variation of trace element concentration in the surface $(0.5 \mathrm{~m})$ layer of Lake Vilno.

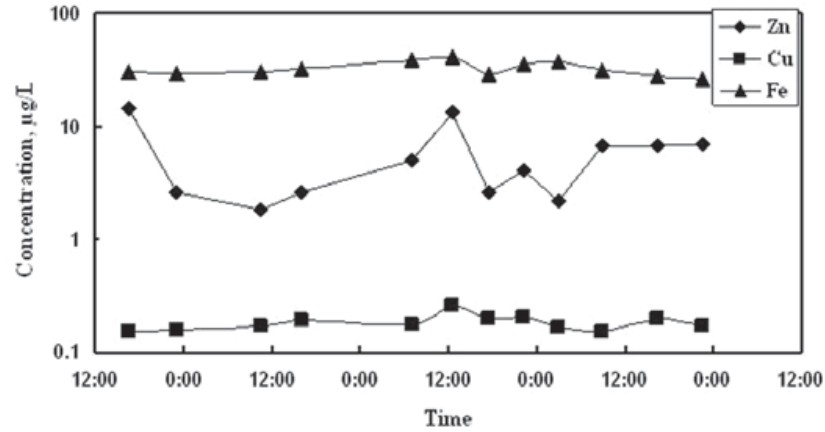

Fig. 5. Diurnal variations of $\mathrm{Fe}, \mathrm{Cu}$ and $\mathrm{Zn}$ concentration at the depth of $4.0 \mathrm{~m}$ of Lake Vilno.

from the adjacent swamps precludes their prompt response to the variation of biological activity in the diurnal cycle. $\mathrm{Zn}$ is known to be less complexed with organic colloids and thus it is more labile during shortterm variations of the environmental parameters in the water column. Unfortunately, due to contamination during dialysis procedure, we were not able to measure the proportion of colloidal fraction of $\mathrm{Cu}$ and $\mathrm{Zn}$ in studied lake. However, from the knowledge of these metals speciation in adjacent boreal zones, they are most likely to be present in small-size organic (fulvic) complexes and simple ions, respectively (Vasyukova et al., 2010). The trace elements are likely to be involved in two major processes controlling their concentration in the lake water: uptake by growing phytoplankton and release during degradation of allochtonous and autochtonous organic matter by heterotrophic bacterioplankton. Our previous results support the possibility of utilization by heterotrophic bacteria of colloidal allochtonous organic matter in boreal surface waters of Arkhangelsk region and Northern Siberia (Shirokova et al., 2008, 2009). By consuming allochtonous dissolved organics, heterotrophic bacteria are also capable of uptaking oligo-elements (limiting nutrients) or releasing biologically-indifferent trace elements. However, even though colloidally-bound trace elements such as trivalent and tetravalent metals are potentially bioavailable for aquatic biota via heterotrophic bacteria pathway, the constant pattern of their concentration with time over period of observation signify the negligible role of intra-lake biological processes (i.e., occurring within the water column) in geochemistry of these elements.

Several trace elements clearly demonstrate diurnal variations in concentration during the observation period (Figs. 6A-6D). These are the biologically important elements such as Mn, Co and Mo, and also Cd. The latter is known to substitute $\mathrm{Zn}$ in the carbonic anhydrase of diatoms in case of $\mathrm{Zn}$ limitation conditions (Lane et al., 2005) and both are significantly affected by the trophic transfer along the foodwebs (Twiss et al., 1996). Peak concentrations of these elements occurred during the second night of monitoring. This coincided with a decrease in concentrations of both eutrophic and oligotrophic bacterioplankton (Fig. 7), and, consequently, may imply a direct link between these elements and heterotrophic bacteria activity. For example, phytoplankton cells and their large-size exometabolites mineralization by heterotrophic bacteria, or the degradation of bacterial biomass may release oligoelements in soluble $(<0.22 \mu \mathrm{m})$ form 



Fig. 6. Diurnal variations of $\mathrm{Mn}(\mathrm{A}), \mathrm{Mo}(\mathrm{B}), \mathrm{Cd}(\mathrm{C})$ and $\mathrm{Co}(\mathrm{D})$ concentration at 0.5 and $4.0 \mathrm{~m}$ depth of Lake Vilno.

in the water column as it is known for $\mathrm{Zn}$ and $\mathrm{Cd}$ from laboratory experiments on degradation and elemental release rates from phytoplankton debris (Lee and Fisher, 1992; Wang and Guo, 2001). However, our data do not allow quantitatively resolve the correlation coefficient between these parameters due to limited number of measurements. The four considered elements are quite contrasting in terms of their colloidal speciation in solution. While Co and Cd are 80-90\% complexed with colloids, $\mathrm{Mn}$ and Mo are linked to colloidal fraction by not more than $20-30 \%$ of their total concentration (Fig. 2A). Therefore, for biologically-important elements, the affinity to plankton biomass is apparently more important for diurnal cycle variation pattern than the speciation in the lake water. It is important to note that both surface and deep lake waters depicted the diurnal variation of these biologically important oligo-elements and bacterioplankton concentration. This strongly implies that the vertical distribution of all hydrochemical and biological

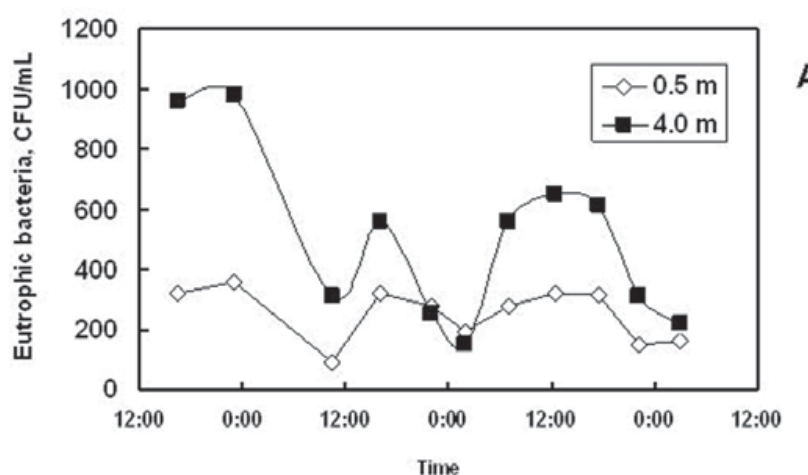

A

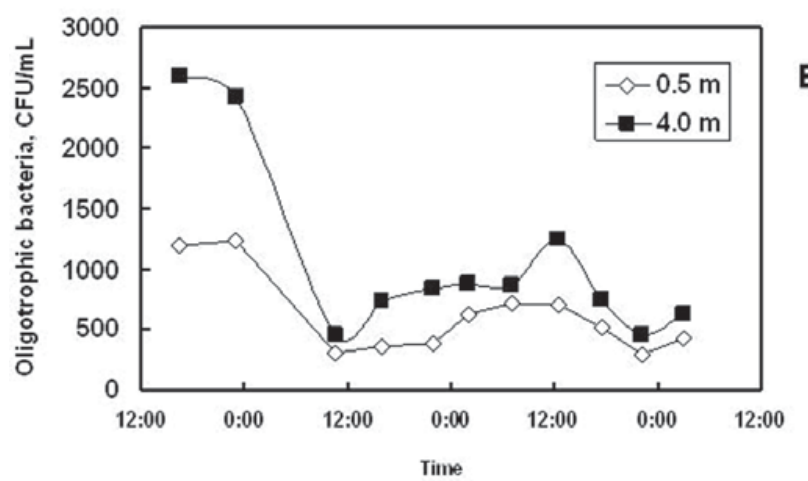

Fig. 7. Diurnal variations of eutrophic (A) and oligotrophic (B) bacterioplankton concentration (colony forming units per $\mathrm{mL}$ ) at 0.5 and $4.0 \mathrm{~m}$ depth of Lake Vilno.

parameters is quite homogeneous and not subjected to summer stratification. This is consistent with the low depth of this lake having high surface area and the absence of bloom event during the sampling period. Another important factor known to control trace element variations along the depth profile in lakes is redox process of $\mathrm{Fe}$ and $\mathrm{Mn}$ oxides dissolution and precipitation (i.e., Davison, 1993). The Mn, Mo, Co and Cd concentration increase after the second night of observation (Fig. 6) is concomitant with dissolved oxygen decrease (Fig. 3C) and may be caused by partial reductive dissolution of $\mathrm{Mn}$ oxides formed in the water column or may be linked to the diffusion flux of metals from the sediments as it is observed in neighboring seasonally-stratified lakes (Pokrovsky et al., 2009). In this regard, Mn, Mo and Co peaks could reflect a benthic response to bacterial biomass accumulation at the sediment interface (e.g., Taillefert et al., 2002).

Overall, results of this work enable two types of element behavior during photosynthesis in the water column to be distinguished: those exhibiting constant concentration (all major elements, anions and neutral molecules, trivalent and tetravalent trace elements tightly linked to organic or organo-mineral colloids) and those demonstrating sinusoidal variations (biologically important heavy metals, oligoelements). Two factors that control to which group the chemical element belongs are: element speciation in solution controlled by the presence of colloids and the element affinity to aquatic microorganisms. 


\section{Conclusions}

We observed a highly constant concentration of many trace and major elements at the depth of 0.5 and $4.0 \mathrm{~m}$ of non-stratified lake during bloom-free period of continuous 4-days observation. Among 40 studied major and trace elements, only $\mathrm{Zn}, \mathrm{Mo}, \mathrm{Mn}, \mathrm{Co}$ and $\mathrm{Cd}$ may be linked to some variations of bacterioplankton concentrations, whereas most of trivalent and tetravalent elements, $\mathrm{Fe}$ and $\mathrm{Cu}$ are strongly complexed with organo-mineral colloids, behave independently of biological and hydrochemical parameters of the water column. It is anticipated that single, one-time sampling from the lake surface $(0.5 \mathrm{~m})$ can be sufficiently representative for a large number of dissolved components. This approach should be extended to verify the functional relationships between geochemical (concentration and speciation of trace element) and microbiological (bacterioplankton and phytoplankton concentration, primary productivity and respiration) parameters during winter conditions and bloom periods in the boreal lake.

Acknowledgements. We are grateful to an anonymous reviewer for thoughtful comments that allowed significant improvement of the manuscript. This work was supported by National EC2CO Programme (Cytrix), and by RFFI grant ( ${ }^{\circ}$ 08-05-98810) and by LEAGE European Associated laboratory. Chris Pearce is thanked for editorial English corrections.

\section{References}

Albéric P., Viollier E., Jézéquel D., Crosbois C. and Michard G., 2000. Interactions between trace elements and dissolved organic matter in the stagnant anoxic deep layer of a meromictic lake. Limnol. Oceanogr., 45, 1088-1096.

Alfaro-De la Torre M.C., Beaulieu P.Y. and Tessier A.T., 2000. In situ measurement of trace metals in lakewater using the dialysis and DGT techniques. Anal. Chim. Acta, 418, 53-68.

Balistrieri L.S., Murray J.W. and Paul B., 1992. The biogeochemical cycling of trace metals in the water column of Lake Sammamish, Washington: Response to seasonally anoxic conditions. Limnol. Oceanogr., 37, 529-548.

Brick C.M. and Moore J.N., 1996. Diel variation of trace metals in the Upper Clark Fork River, Montana. Environ. Sci. Technol., 30, 1953-1960.

Carignan R., Rapin F. and Tessier A., 1985. Sediment porewater sampling for metal analysis: A comparison of techniques. Geochim. Cosmochim. Acta, 49, 2493-2497.

Dahlqvist R., Andersson K., Ingri J., Larsson T., Stolpe B. and Turner D., 2007. Temporal variations of colloidal carrier phases and associated trace elements in a boreal river. Geochim. Cosmochim. Acta, 71, 5339-5354.

Davison W., 1993. Iron and manganese in lakes. Earth Sci. Rev., 34, 119-163.

de Caritat P., Reimann C., Äyräs M., Niskavaara H., Chekushin V.A. and Pavlov V.A., 1996. Composition of stream water from eight catchments on the Kola Peninsula (NW Russia) and in neighbouring areas of Finland and Norway: 1. Element levels and sources. Aquatic Geochem., 2, 149-168.
Eiler A., Olsson J.A. and Bertilsson S., 2006. Diurnal variations in the auto- and heterotrophic activity of cyanobacterial phycospheres (Gloeotrichia echinulata) and the identity of attached bacteria. Freshwat. Biol., 51, 298-311.

Emmenegger L., Schonenberger R., Sigg L. and Sulzberger B., 2001. Light-induced redox cycling of iron in circumneutral lakes. Limnol. Oceanogr., 46, 49-61.

Falkner K.K., Church M., Measures C.I., Lebaron G., Thouron D., Jeandel C., Stordal M.C., Gill G.A., Mortlock R., Froelich P. and Chan L.-H., 1997. Minor and trace element chemistry of lake Baikal, its tributaries, and surrounding hot springs. Limnol. Oceanogr., 42, 329-345.

Gammons C.H., Nimick D.A., Parker S.R., Cleasby T.E. and McCleskey R.B., 2005a. Diel behavior of iron and other heavy metals in a mountain stream with acidic to neutral $\mathrm{pH}$ : Fisher Creek, Montana, USA. Geochim. Cosmochim. Acta, 69, 2505-2516.

Gammons C.H., Wood S.A. and Nimick D.A., 2005b. Diel behavior of rare earth elements in a mountain stream with acidic to neutral pH. Geochim. Cosmochim. Acta, 69, 37473758.

Gélabert A., Pokrovsky O.S., Viers J., Schott J., Boudou A. and Feurtet-Mazel A., 2006. Interaction between zinc and freshwater and marine diatom species: Surface complexation and $\mathrm{Zn}$ isotope fractionation. Geochim. Cosmochim. Acta, 70, 839-857.

Gélabert A., Pokrovsky O.S., Schott J., Boudou A. and FeurtetMazel A., 2007. Cadmium and lead interaction with diatom surfaces: a combined thermodynamic and kinetic approach Geochim. Cosmochim. Acta, 71, 3698-3716.

Gimpel J., Zhang H., Davison W. and Edwards A., 2003. In situ trace metal speciation in lake surface waters using DGT, dialysis, and filtration. Environ. Sci. Technol., 37, 138146.

Hamilton-Taylor J. and Willis M., 1990. A quantitative assessment of the sources and general dynamics of trace metals in a soft-water lake. Limnol. Oceanogr., 35, 840-851.

Hamilton-Taylor J., Davison W. and Morfett K., 1996. The biogeochemical cycling of $\mathrm{Zn}, \mathrm{Cu}, \mathrm{Fe}, \mathrm{Mn}$, and dissolved organic $\mathrm{C}$ in a seasonally anoxic lake. Limnol. Oceanogr., 41, 408-418.

Hamilton-Taylor J., Smith E.J., Davison W. and Sugiyama M., 2005. Resolving and modeling the effects of $\mathrm{Fe}$ and $\mathrm{Mn}$ redox cycling on trace metal behavior in a seasonally anoxic lake. Geochim. Cosmochim. Acta, 69, 1947-1960.

Hutchinson G.E., 1957. A Treatise on Limnology, Vol. 1, Wiley, New York.

Ingri J., Widerlund A., Land M., Gustafsson Ö., Andersson P.S. and Öhlander B., 2000. Temporal variations in the fractionation of the rare earth elements in a boreal river, the role of colloidal particles. Chem. Geol., 166, 23-45.

Jones C.A., Nimick D.A. and McCleskey R.B., 2004. Relative effect of temperature and $\mathrm{pH}$ on diel cycling of dissolved trace elements in Prickly Pear creek, Montana. Water Air Soil Pollut., 153, 95-113.

Kritzberg E.S., Cole J.J., Pace M.L., Granéli W. and Bade D.L., 2004. Autochtonous versus allochtonous carbon sources of bacteria: results from whole-lake $13 \mathrm{C}$ addition experiments. Limnol. Oceanogr., 49, 588-596.

Lane T.W., Saito M.A., George G.N., Pickering I.J., Prince R.C. and Morel F.M.M., 2005. A cadmium enzyme from a marine diatom. Nature, 435, 42. 
Lee B.-G. and Fisher N.S., 1992. Degradation and elemental release rates from phytoplankton debris and their geochemical implications. Limnol. Oceanogr., 37, 1345-1360.

Luengen A.C., Raimondi P.T. and Flegal A.R., 2007. Contrasting biogeochemistry of six trace metals during the rise and decay of a spring phytoplankton bloom in San Francisco Bay. Limnol. Oceanogr., 52, 1112-1130.

McMahon J.W., 1969. The annual and diurnal variation in the vertical distribution of acid-soluble ferrous and total iron in a small dimictic lake. Limnol. Oceanogr., 14, 357-367.

Nimick D.A., Cleasby Th.E. and McCleskey R.B., 2005. Seasonality of diel cycles of dissolved trace-metal concentrations in a Rocky Mountain stream. Environ. Geol., 47, 603614.

Noel R., Urban N.R., Gorham E., Underwood J.K., Martin F.B. and Ogden III J.G., 1990. Geochemical processes controlling concentrations of $\mathrm{Al}, \mathrm{Fe}$, and $\mathrm{Mn}$ in Nova Scotia lakes. Limnol. Oceanogr., 35, 1516-1534.

Nriagu J.O., Lawson G., Wong H.K.T. and Cheam V., 1996. Dissolved trace metals in lakes Superior, Erie, and Ontario. Environ. Sci. Technol., 30, 178-187.

Parker S.R., Gammons C.H., Jones C.A. and Nimick D.A., 2007. Role of hydrous iron oxide formation in attenuation and diel cycling of dissolved trace metals in a stream affected by acid rock drainage. Water Air Soil Pollut., 181, 247-263.

Pokrovsky O.S. and Schott J., 2002. Iron colloids/organic matter associated transport of major and trace elements in small boreal rivers and their estuaries (NW Russia). Chemical Geol., 190, 141-179.

Pokrovsky O.S., Dupré B. and Schott J., 2005. Fe-Al-organic colloids control of trace elements in peat soil solutions. Aquat. Geochem., 11, 241-278.

Pokrovsky O.S., Schott J. and Dupré B., 2006. Trace element fractionation and transport in boreal rivers and soil porewaters of permafrost-dominated basic terrain in Central Siberia. Geochim. Cosmochim. Acta, 70, 3239-3260.

Pokrovsky O.S., Martinez R., Golubev S.V., Kompantzeva E.I. and Shirokova L.S., 2008a. Adsorption of metals and protons on Gloeocapsa sp. cyanobacteria: A surface speciation approach. Appl. Geochem., 23, 2574-2588.

Pokrovsky O.S., Viers J., Emnova E.E., Kompantseva E.I. and Freydier R., 2008b. Copper isotope fractionation during its adsorption on soil and aquatic bacteria and metal hydroxides: possible structural control. Geochim. Cosmochim. Acta, 72, 1742-1757.

Pokrovsky O.S., Shirokova L.S. and Viers J., 2009. Geochemistry of trace elements in boreal stratified lakes during different seasons, International Meeting - Lake Pavin and Other Meromictic Lakes, May 14-16 2009, Besse-etSaint-Anastaise.

Reynolds G.L. and Hamilton-Taylor J., 1992. The role of planktonic algae in the cycling of $\mathrm{Zn}$ and $\mathrm{Cu}$ in a productive soft-water lake. Limnol. Oceanogr., 37, 1759-1769.

Roederer J.G., 1991. Understanding the Arctic: Research policies and responsibilities. In: Sturges W.T. (ed.), Pollution of the Arctic Atmosphere, N.Y., Elsewhere, 1-11.

Rose M., 1925. Contribution à l'étude de la biologie du plancton. Le problème des migrations verticales journalières. Arch. Zool. Exper., 64, 387-542.

Shirokova L.S. and Pokrovsky O.S., 2008. DOC speciation in boreal rivers and lakes and its link with microbial biomass, bacterioplankton production and degradation. Geophysical Research Abstracts, 10, EGU2008-A-03462, SRef-ID: 16077962/gra/EGU2008-A-03462.

Shirokova L.S., Pokrovsky O.S., Kirpotin S.N. and Dupré B., 2009. Heterotrophic bacterio-plankton in thawed lakes of northern part of Western Siberia controls the $\mathrm{CO}_{2}$ flux to the atmosphere. Int. J. Environ. Stud., 66, 433-445.

Smith L.C., Macdonald G.M., Velichko A.A., Beilman D.W., Borisova O.K., Frey K.E., Kremenetsky K.V. and Sheng Y., 2004. Siberian peatlands as a net carbon sink and global methane source since the early Holocene. Science, 303, 353 356.

Taillefert M., MacGregor B.J., Gaillard J.-F., Lienemann C.-P., Perret D. and Stahl D.A., 2002. Evidence for a dynamic cycle between $\mathrm{Mn}$ and $\mathrm{Co}$ in the water column of a stratified lake. Environ. Sci. Technol., 36, 468-476.

Tranvik L., 1988. Availability of dissolved organic carbon for planktonic bacteria in oligotrophic lakes of differing humic content. Microbiol. Ecol., 16, 311-322.

Tranvik L., 1989. Bacterioplankton growth, grazing mortality and quantitative relationship to primary production in a humic and a clearwater lake. J. Plankton Res., 11, 985-1000.

Tranvik L., 1994. Effects of colloidal organic matter on the growth of bacteria and protists in lake water. Limnol. Oceanogr., 39, 1276-1285.

Tripathi B.N., Kasana R., Singh V., Bhatt I., Singh A., Sharma V. and Gaur J.P., 2009. Carotenoids and pH of the culture medium play an important role in displaying metal stress in batch and semi-continuous cultures of Anabaena doliolum. Ann. Limnol. - Int. J. Lim., 45, 119-125.

Twiss M.R., Campbell P.G.C. and Auclair J.-C., 1996. Regeneration, recycling, and trophic transfer of trace metals by microbial food-web organisms in the pelagic surface waters of Lake Erie. Limnol. Oceanogr., 41, 1425-1437.

Vasyukova E.V., Pokrovsky O.S., Viers J., Oliva P., Dupré B., Martin F. and Candaudap F., 2010. Trace elements in organic- and iron-rich surficial fluids of the Boreal zone: Assessing colloidal forms via dialysis and ultrafiltration. Geochim. Cosmochim. Acta, 74, 449-468.

Viollier E., Jézéquel D., Michard G., Pèpe M., Sarazin G. and Albéric P., 1995. Geochemical study of a crater lake (Pavin Lake, France): trace-element behaviour in the monimolimnion. Chem. Geol., 125, 61-72.

Viollier E., Michard G., Jézéquel D., Pèpe M. and Sarazin G., 1997. Geochemical study of a crater lake: Lake Pavin, Puy de Dôme, France. Chem. Geol., 142, 225-241.

Wang W.-X. and Guo L., 2001. Production of colloidal organic carbon and trace metals by phytoplankton decomposition. Limnol. Oceanogr., 46, 278-286.

Xue H. and Sigg L., 1993. Free cupric ion concentration and $\mathrm{Cu}$ (II) speciation in a eutrophic lake. Limnol. Oceanogr., 38, $1200-1213$.

Yeghicheyan D., Carignan J., Valladon M., Bouhnik Le Coz M., Le Cornec F., Castrec-Rouelle M., Robert M., Aquilina L., Aubry E., Churlaud C., Dia A., Deberdt S., Dupré B., Freydier R., Gruau G., Hénin O., de Kersabiec A.M., Macé J., Marin L., Morin N., Petitjean P. and Serrat E., 2001. A compilation of silicon and thirty one trace elements measured in the natural river water reference material SLRS-4 (NRC-CNRC). Geostandards Newsletter, 25, 465474. 